\title{
Apparent Discrepancy between the Insulin Secretory Responses in Vivo and in Vitro in Carbohydrate-Intolerant Sand Rats
}

\author{
H. J. Hahn, H. D. Gottschling, and H. Schäfer \\ Departments of Experimental Diabetes Research and Central Laboratory, Central Institute for Diabetes, Karlsburg, G.D.R.
}

\begin{abstract}
Summary. A subpopulation $(\mathrm{n}=27)$ of normoglycaemic Sand rats was characterized as carbohydrateintolerant by intraperitoneal glucose loading. Five of these animals did not show any rise in peripheral insulin concentrations when injected with glucose. However, when isolated by collagenase digestion their islets still exhibited a significant enhancement of insulin secretion in response to glucose, glyceraldehyde, mannose and theophylline. The in vitro secretory responses were comparable to those of islets from carbohydrate-tolerant Sand rats. The results underline the importance of the natural environment for the B-cell response in vivo.
\end{abstract}

Key words: Sand rat, insulin secretion, glucose loading, isolated islet, insulin content.

Hackel et al. [1] reported that normoglycaemic and normoinsulinaemic Sand rats with a decreased carbohydrate tolerance are occasionally characterized by a total $\mathrm{B}$-cell unresponsiveness in vivo. We have also observed similar in vivo behaviour in some Sand rats. In the present study we have investigated whether islets isolated from these animals are capable of releasing insulin in vitro.

\section{Material and Methods}

52 Sand rats of both sexes were taken from a local colony and loaded with $2.0 \mathrm{~g}$ glucose IP under light hexobarbital anaesthesia as earlier described [2]. Blood samples for measurement of glucose [3] and insulin [4] were taken from the orbital vein plexus after 0 , $10,30,80$, and $120 \mathrm{~min}$. Normal glucose and insulin concentrations were established, using 48 Sand rats, fed with a low-calorie diet [5]. The following criteria were used to define a normal carbohydrate tolerance:
1. Normoglycaemia at $0 \mathrm{~min}$ within $91 \pm 34 \mathrm{mg} / 100 \mathrm{ml}$ (mean $\pm 2 \mathrm{SD})$

2. Normoinsulinaemia at $0 \mathrm{~min}$ within $3.39 \pm 2.32 \mathrm{ng} / \mathrm{ml}$ (mean $\pm 2 \mathrm{SD}$ )

3. Peak of blood glucose at $10 \mathrm{~min}$ and thereafter a continuous decrease to normal within $120 \mathrm{~min}$.

4. Peak of insulin at $10 \mathrm{~min}$ and normalization within $120 \mathrm{~min}$.

According to these criteria, 8 animals were normal and 27 were normoglycaemic and normoinsulinaemic, but carbohydrate-intolerant (blood glucose not normalized in $120 \mathrm{~min}$ ). Among the 27 carbohydrate-intolerant Sand rats, 5 did not show any significant changes in peripheral insulin concentration in response to the glucose injection. Those 5 animals, as well as the 8 normal ones were investigated with respect to the in vitro response of their isolated islets.

The Sand rats were decapitated 2-12 days (normal rats) or 3-15 days (carbohydrate-intolerant rats) after the in vivo test. Again, blood glucose and plasma insulin were determined. Immediately after collagenase-isolation [6] groups of 5 islets from each animal were used to measure the islet insulin content [7]. Islets of similar size (140-190 $\mu \mathrm{m}$ in diameter) were incubated for $30 \mathrm{~min}$ at $37^{\circ} \mathrm{C}$ in Krebs-Ringer-bicarbonate buffer [8] $(\mathrm{pH} 7.4$; $95 \% \quad 0_{2}, 5 \% \quad \mathrm{CO}_{2}$ ) supplemented with $2.5 \mathrm{mmol} / 1$ glucose, $27.5 \mathrm{mmol} / 1$ sucrose, $1 \mathrm{mg} / \mathrm{ml}$ bovine serum albumin and $16 \mathrm{mmol} / 1$ HEPES (N-2-hydroxyethylpiperazine-N'-2-ethanesulphonic acid). Groups of 5 islets were then incubated for $60 \mathrm{~min}$ at $37^{\circ} \mathrm{C}$ in the same type of buffer without glucose, or with $1.7 \mathrm{mmol} / 1,5 \mathrm{mmol} / 1,15 \mathrm{mmol} / 1,30 \mathrm{mmol} / 1 \mathrm{D}$-glucose, $30 \mathrm{mmol} /$ $1 \mathrm{D}$-mannose, $1.7 \mathrm{mmol} / 1 \mathrm{D}$-glucose $+5 \mathrm{mmol} / \mathrm{l} \mathrm{D}$-glyceraldehyde or $15 \mathrm{mmol} / \mathrm{l} \mathrm{D}$-glucose $+5 \mathrm{mmol} / 1$ theophylline. After the incubation the buffer was separated from the tissue and radioimmunologically assayed for insulin [9] with rat insulin as reference (Lot R 170, NOVO Industries Copenhagen).

Results are given as mean values \pm SEM for the indicated numbers of experiments. Data were analyzed for statistical significance using Student's t test for unpaired comparisons.

\section{Results}

Normal and carbohydrate-intolerant animals did not differ in age, body-weight, postprandial blood glucose, basal plasma insulin, islet insulin content, or pancreas wet weight (Table 1). Fig. 1 summarizes the 
Table 1. Characteristics of normal and glucose intolerant Sand rats

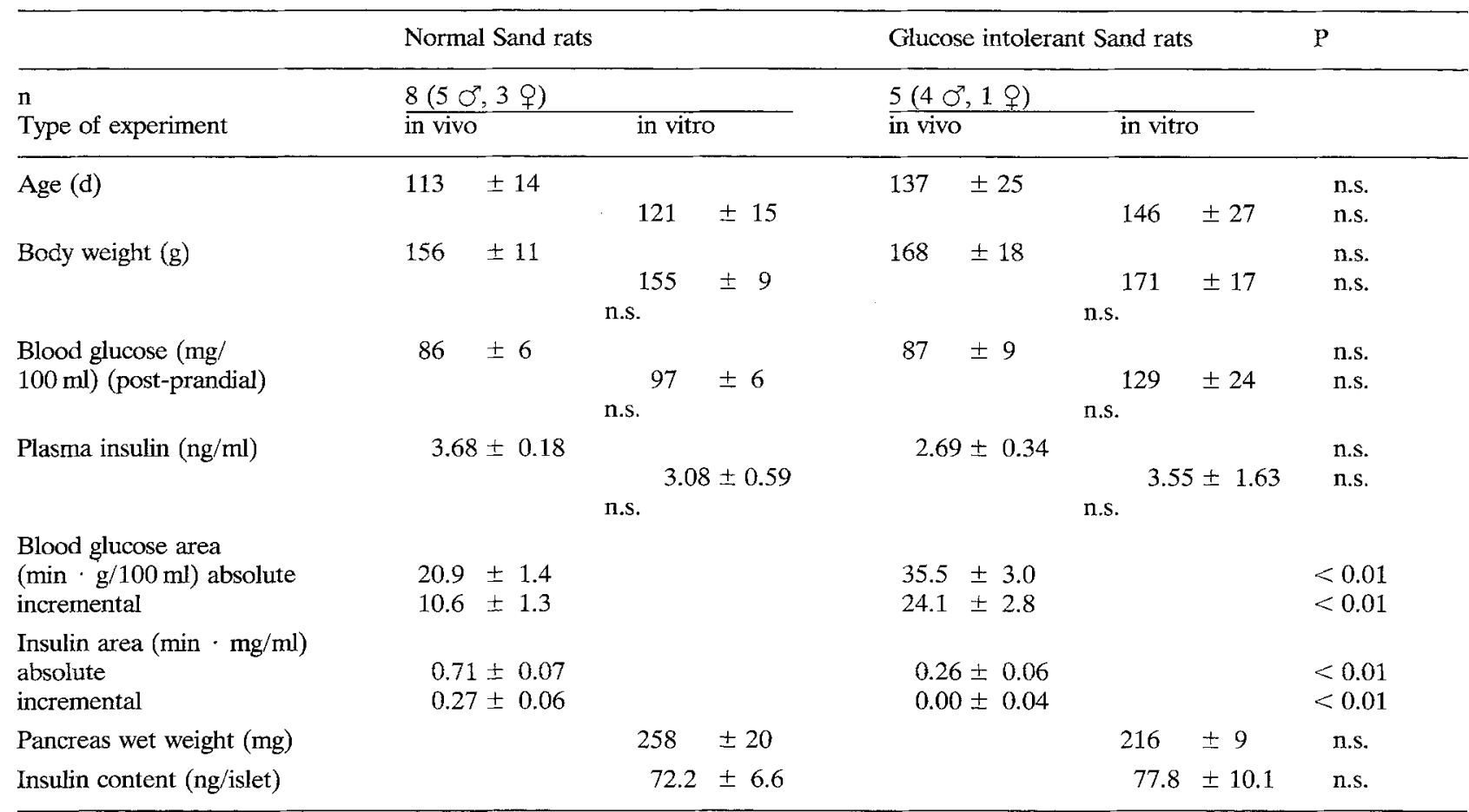
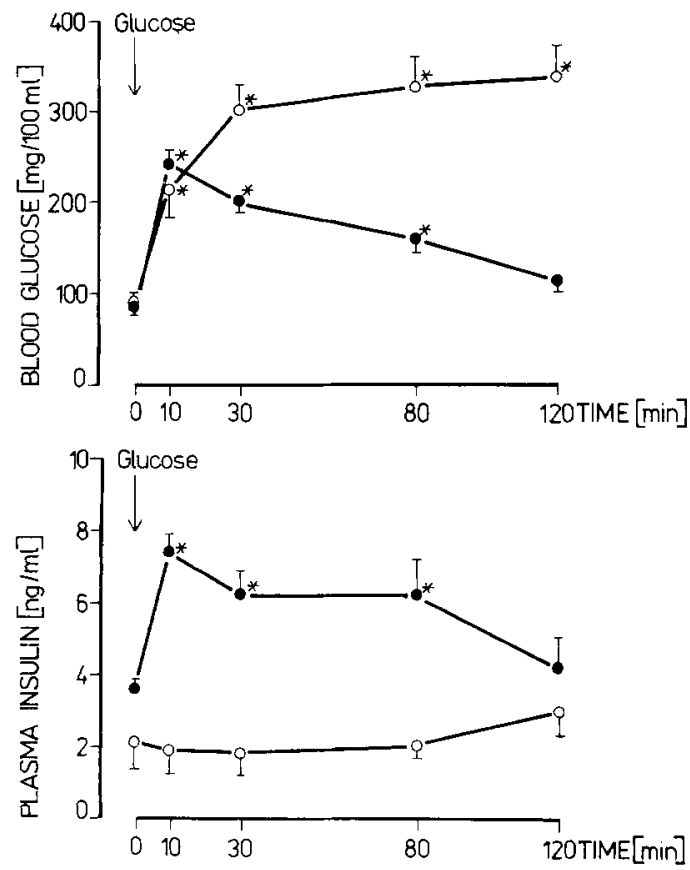

Fig. 1. Blood glucose (upper part) and plasma insulin (lower part) after glucose loading in normal (_- ) and carbohydrate-intolerant $\left(\mathrm{O}^{-} \mathrm{O}\right)$ Sand rats. $* \mathrm{P}<0.01$ compared to 0 min within the investigated group of animals results of the intraperitoneal glucose tolerance tests. In contrast to the normal Sand rats, the carbohydrate-intolerant animals exhibited steady hyperglycaemia (above $300 \mathrm{mg} / 100 \mathrm{ml}$ ) from 30 minutes onwards and showed no measurable change in peripheral insulin concentration.

As shown in Fig. 2, islets from both normal and carbohydrate-intolerant Sand rats released insulin briskly when challenged with glucose $(\mathrm{P}<0.01$ compared with basal), mannose $(\mathrm{P}<0.01)$, glyceraldehyde $(\mathrm{P}<0.01)$, and theophylline $(\mathrm{P}<0.01)$ in vitro. Both types of islets displayed a sigmoidal doseresponse curve for glucose with a threshold below $5 \mathrm{mmol} / 1$.

\section{Discussion}

Hackel et al. [1] described the occurrence of normoglycaemic, carbohydrate-intolerant Sand rats which did not respond to hyperglycaemia in vivo with enhanced insulin secretion. In our Sand rat colony we have already confirmed this observation in some, but not all carbohydrate-intolerant animals [5]. The present results demonstrate that the pancreases of such carbohydrate-intolerant Sand rats contain islets 


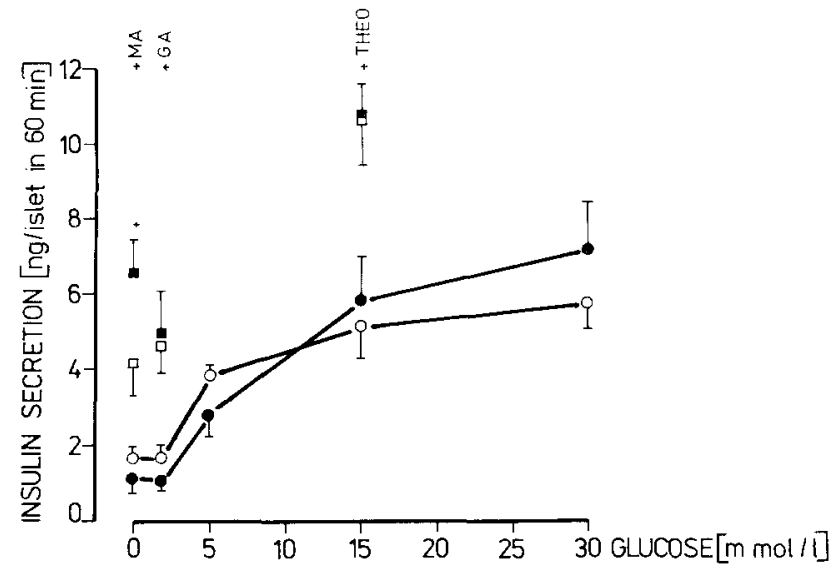

Fig. 2. Insulin secretion of isolated islets prepared from normal $(-)$ ) or carbohydrate-intolerant $(\mathrm{O}-\mathrm{O})$ Sand rats in response to glucose. The secretory responses to some other stimuli (MA: $30 \mathrm{mmol} / 1$ Mannose; GA: $5 \mathrm{mmol} / 1$ Glyceraldehyde; THEO: $5 \mathrm{mmol} / 1$ Theophylline) at various glucose concentrations are also shown for normal ( $\square$ ) and carbohydrate-intolerant $(\square)$ Sand rats

which respond apparently normally to a variety of stimuli in vitro. Moreover, the islets from the in vivo glucose-insensitive Sand rats contained as much insulin as the normal controls. The discrepancy between the in vivo and in vitro results was probably not due to a spontaneous remission of the carbohydrate intolerance during the short period elapsing between the intraperitoneal glucose load and the experiments with isolated islets. The blood glucose, plasma insulin and body weight at the time of the in vitro experiment did not differ significantly from the values recorded at the time of the glucose tolerance test. If anything, the blood glucose of the carbohydrate-intolerant Sand rats tended to increase in the course of the study (Table 1 ).

It is not known whether this behaviour of the pancreatic B-cells is in any way important for the development of diabetes. However, the results underline the importance of humoral, neural, and other influences (e.g. exogenous during the glucose tolerance test; [10]) for the expression of B-cell activity in vivo. Therefore, investigations of the peripheral insulin concentration under certain conditions may not be entirely representative for the endogenous B-cell capacity to secrete insulin in response to various stimuli.
Acknowledgements. The authors thank Drs. I. B. Täljedal (Dept. Histology, University Umeå) and K. G. M. M. Alberti (Dept. Clinical Biochemistry, University Newcastle-upon-Tyne) for critical advice and helpful discussions.

\section{References}

1. Hackel, D. B., Frohman, L., Mikat, E., Lebovitz, H. E., Schmidt-Nielsen, K., Kinney, T. D.: Effect of diet on the glucose tolerance and plasma insulin levels of the sand rat (Psammomys obesus). Diabetes 15, 105-114 (1966)

2. Hahn, H. J., Schäfer, H., Gottschling, H. D., Fiedler, H.: Insulin and glucagon secretion by pancreatic islets from nondiabetic and diabetic sand rats (Psammomys obesus). Eur. J. Clin. Invest. 6, 85-91 (1976)

3. Stork, M., Schmidt, F.H.: Mitteilung über eine enzymatische Schnellmethode zur Bestimmung des Blutzuckers in $5 \mu \mathrm{l}$ Kapillarblut ohne Enteiweissung und ohne Zentrifugation. Klin. Wochenschr. 46, 789-790 (1968)

4. Gottschling, H.D., Ziegler, M., Wilke, W., Michael, R.: Radioimmunoassay von Plasmainsulin - methodenkritische Untersuchungen. Radiobiol. Radiother. (Berl.) 15, 91-97 (1974)

5. Hahn, H. J.: Die isolierte Langerhans'sche Insel als ein Modell zur quantitativen Untersuchung der Insulin- und Glukagonsekretion in vitro. Promotion B, Universität Greifswald, Medizinische Fakultät, 1977

6. Hahn, H. J., Lippmann, H. G., Schultz, D.: Das Verhalten der Langerhans'schen Inseln des Pankreas in vitro: Isoliertechnik und Methodenkritik. Acta Biol. Med. Ger. 25, 421-431 (1970)

7. Hahn, H. J., Hellman, B., Lernmark, A., Täljedal, I. B.: Verändenung der Insulinsekretion isolierter Langerhans'scher Inseln durch Behandlung mit Neuraminidase. Acta Biol. Med. Ger. 32, 375-383 (1974)

8. Umbreit, W.W., Burris, R.H., Stauffer, J.F.: Manometric techniques. 4th ed. Minneapolis: Burgess Publishing Company 1964

9. Speck, G. A., Ziegler, B., Hahn, H. J., Ziegler, M.: Radioimmunoassay der immunreaktiven Insulinaktivitäten Langerhans'scher Inseln. Radiobiol. Radiother. (Berl.) 15, 85-89 (1974)

10. Mikat, E. M., Hackel, D. B., Cruz, P. P., Lebovitz, H. E.: Lowered glucose tolerance in the sand rat (Psammomys obesus) resulting from esophageal intubation. Proc. Soc. Exp. Biol. Med. 139, 1390-1391 (1972)

Received: April 3, 1979, and in revised form: June 25, 1979

Dr. sc. med. H. J. Hahn

Department of Experimental Diabetes Research

Central Institute for Diabetes

Research and Treatment

DDR-2201 Karlsburg

German Democratic Republic 